Al pha- gl ucosi dase- I i ke act i vity det ected i n a si bogl i ni d pol ychaete, a i gobr achi a mashi koi

\begin{tabular}{|l|l|}
\hline 著者 & Koi zumi Takashi, Sasayama Yui chi \\
\hline $\begin{array}{l}\text { j our nal or } \\
\text { publ i cat i on ti t l e }\end{array}$ & Zool ogi cal Sci ence \\
\hline vol une & 25 \\
\hline number & 4 \\
\hline page r ange & 364 371 \\
\hline year & 2008 O4 01 \\
\hline URL & ht t p: //hdl . handl e. net /2297/10950 \\
\hline
\end{tabular}




\title{
Alpha-Glucosidase-like Activity Detected in a Siboglinid Polychaete, Oligobrachia mashikoi
}

\author{
Takashi Koizumi $^{1 *}$ and Yuichi Sasayama ${ }^{2}$ \\ ${ }^{1}$ Department of Life science, Graduate School of Natural Science and Technology, \\ Kanazawa University, Kanazawa 920-1192, Japan \\ ${ }^{2}$ Noto Marine Laboratory, Institute of Nature and Environmental Technology, \\ Kanazawa University, Kanazawa 920-1192, Japan
}

\begin{abstract}
Siboglinid worms live on carbohydrates produced by symbiotic bacteria. In this study, $\alpha$-glucosidaselike activity was detected in the surface of the body and in the trophosome of Oligobrachia mashikoi. The enzyme exhibiting this activity was partially purified by consecutively applying the crude enzyme extract to Con-A-Sepharose and Sephadex-200 HR columns. The enzyme sample thus obtained gave a single activity peak at a position corresponding to $550 \mathrm{kDa}$ in the Sephadex$200 \mathrm{HR}$ gel filtration column. The enzyme was active in the range of $\mathrm{pH}$ 6.0-8.0, with a maximum activity at around $\mathrm{pH}$ 6.5. It specifically hydrolyzed maltose, and was inhibited by voglibose and miglitol. Moreover, a glucose transporter 2-like protein was detected by immunohistochemical and Western-blotting analyses using anti-rat GLUT2 polyclonal antibody. These results raise the question how this unique species lives.
\end{abstract}

Key words: $\alpha$-glucosidase-like activity, beard worm, glucose intake, glucose transporter, epidermis

\section{INTRODUCTION}

Beard worms and tubeworms of Siboglinidae (Annelida), lacking both a mouth and a digestive tract, harbor chemosynthetic bacteria in the trophosome and live on carbohydrates produced by the bacteria. In tubeworms inhabiting hydrothermal vents where hydrogen sulfide levels are high (Schulze et al., 2003), the trophosome develops along nearly the entire body. The cells harboring chemosynthetic bacteria, called bacteriocytes, are arranged systematically (Bright and Sorgo, 2003). Furthermore, in tubeworms, the symbiotic bacteria occupy $24.1 \%$ of the volume of the trophosome (Bright and Sorgo, 2003). On the other hand, beard worms prefer to inhabit cold seeps in which hydrogen sulfide levels are rather low compared with those in the tubeworm environment (Schulze et al., 2003). In beard worms, there is no systematic organization of the bacteriocytes in the trophosome, unlike that seen in tubeworms (Southward, 1982; Deguchi et al., 2007). Since the beard worm trophosome is limited to the posterior region of the body, bacteria occupy no more than $1 \%$ of the body volume (Southward, 1982). Therefore, based on the results of using ${ }^{14} \mathrm{C}$ labeled glucose and amino acid residues to study beard worms, Southward et al. $(1972,1981)$ suggested the possible intake of nourishment from the environment.

Tsukumo Bay, in the Noto Peninsula of Ishikawa Prefecture, Japan, is a shallow sea into which the warm Tsushima current flows. The bay is inhabited by one beard worm species, Oligobrachia mashikoi. Since it belongs to genus

\footnotetext{
* Corresponding author. Phone: +81-76-264-6307; Fax : +81-76-264-6230;

E-mail : takashi_koizumi@ pharm.kissei.co.jp
}

Oligobrachia, which is taxonomically primitive (Sasayama et al., 2003), the lifestyle of this species may remain primitive. Therefore, from the viewpoint of the evolution of siboglinid polychaetes, the nutrition intake system of this species is interesting.

Alpha $(\alpha)$-glucosidase is a typical exo-type enzyme that removes glucose from polysaccharides by hydrolyzing the $\alpha$-glucosyl bond at the non-reducing terminus of the substrate. In the mammalian small intestine, this enzyme is involved in the terminal digestion of carbohydrates such as starch (Kellett, 2001; Krasikov et al., 2001; Roach, 2002). Furthermore, the enzyme is distributed widely throughout all organisms and exhibits various specificities for substrates from small molecules, such as oligosaccharides, to large molecules, such as starch and glycogen.

We found $\alpha$-glucosidase-like activity in extracts from $O$. mashikoi. In this study, we investigated where this activity is present and discussed its possible roles, and we also investigated the presence of glucose transporter 2-like protein.

\section{MATERIALS AND METHODS}

\section{Sampling}

We collected O. mashikoi and sampled the mud of its habitat by using dredge gear, as was done in previous sampling (Sasayama et al., 2003). The individuals collected were pushed out from their tubes with a syringe containing seawater. After washing in sterilized seawater, each body was divided under a dissecting microscope into the section anterior to the girdles, which does not contain the trophosome (anterior section), and the section posterior to the girdles, which contains the trophosome (posterior section). The two sections were immediately frozen at $-80^{\circ} \mathrm{C}$ until analyses for enzyme activity. The mud was kept at $-30^{\circ} \mathrm{C}$. 
Table 1. Environmental factors in Tsukumo Bay

\begin{tabular}{lll}
\hline Factor & Sample & Result \\
\hline Water temperature & Seawater & $10 \sim 23^{\circ} \mathrm{C}$ \\
Water content & Mud & $60.3 \pm 1.2 \%$ \\
Total nitrogen* & Mud & $1 \sim 1.5 \mu \mathrm{g} / \mathrm{mg} \mathrm{dry} \mathrm{mud}$ \\
Total sulfide* & Mud & $0.36 \sim 0.46 \mathrm{mg} / \mathrm{g}$ dry mud \\
$\mathrm{pH}$ & Seawater & $8.22 \pm 0.02$ \\
& Mud & $7.56 \pm 0.07$ \\
& Centrifuged supernatant of mud & $7.45 \pm 0.04$ \\
Carbohydrate concentration (as glucose) & Centrifuged sediment of mud & $7.88 \pm 0.11$ \\
& Seawater & Not detected \\
& Centrifuged supernatant of mud & $416.04 \pm 39.63 \mu \mathrm{mol} / \mathrm{L}$ \\
Maltose concentration & Centrifuged sediment of mud & $99.13 \pm 23.73 \mu \mathrm{mol} / \mathrm{L}$ \\
\hline
\end{tabular}

Each value is the mean \pm SEM $(\mathrm{N}=5)$.

*: Data from Sasayama et al. (2007).

\section{Analysis of mud}

In addition to the measurement of water content and $\mathrm{pH}$ levels, total carbohydrate content was examined by the anthrone-sulfuric acid method. The mud was centrifuged at $20,000 \times \mathrm{g}$ for $20 \mathrm{~min}$ at $4^{\circ} \mathrm{C}$. Twenty microliters of the supernatant was added to $200 \mu \mathrm{l}$ of $0.2 \%$ anthrone reagent $(2 \mathrm{mg}$ anthorone $/ 1 \mathrm{ml} 75 \%$ sulfuric acid). After mixing, the solution was immediately transferred to a heat block at $75^{\circ} \mathrm{C}$ and kept there for $30 \mathrm{~min}$. After that, the reaction was stopped in iced water. The total carbohydrate content was determined by measuring the absorbance of the solution at a wavelength of $620 \mathrm{~nm}$. The value was converted to glucose concentration by using a standard curve for glucose. Maltose and glucose concentrations were also directly measured by the UV method with an FKit (J. K. International, Inc., Tokyo).

\section{Protein extraction}

Protein extraction was conducted by using a ProteoExtract subcellular proteome extraction kit (Calbiochem, Tokyo). The two frozen sections were defrosted on ice, and the cytosolic protein fraction (CPF) and membrane/organelle protein fraction (MOPF) were separated. In addition, the quantity of protein was examined using the Lowry method or BCA protein assay method.

Fractionation of molecule(s) exhibiting $\alpha$-glucosidase-like activity Concanavalin A (Con A) column. The CPF and MOPF were added to Slide-A-Dialysis cassettes (Pierce, IL, USA) and dialyzed three times by a buffer solution (20 mM Tris- $\mathrm{HCl}, 0.5 \mathrm{M} \mathrm{NaCl}, 1 \mathrm{mM}$ $\mathrm{MgCl}_{2}, 1 \mathrm{mM} \mathrm{CaCl}_{2}, \mathrm{pH}$ 7.4). The remaining solution in the cassette was concentrated to about $2 \mathrm{ml}$ using an Amicon Ultra-4 centrifugal filter device (Japan Milipore, Tokyo). The solution was separated into two fractions, only one of which contained proteins binding with Con $\mathrm{A}$. For elution of the protein bound to Con $\mathrm{A}$, a gradient solution $(0-100 \mathrm{mM})$ of methyl- $\alpha$-D-glucopyranoside was used.

Gel-filtration column. The fraction exhibiting activity was that not binding to Con A. This fraction was separated by gel filtration with a Superdex-200 HR 10/30 column (GE Healthcare, Tokyo) using the Akta-Purifier chromatographic system (GE Healthcare, Tokyo). As a gel filtration buffer, Tris- $\mathrm{HCl}$ buffer ( $\mathrm{pH}$ 7.6) containing $10 \%$ glycerol was used. The molecular weight of the substance(s) exhibiting the activity was then estimated. As standard molecular markers, thyroglobulin $(669,000)$, ferritin $(443,000)$, lactate dehydrogenase $(139,850)$, and albumin $(66,267)$ were used.

\section{Alpha $(\alpha)$-glucosidase-like activity}

Activity was examined by measuring the rate of increase in fluorescence when $\alpha$-D-glucopyranoside combined with a fluorescence substrate (4-methyl-umbelliferone; 4MUF) was decomposed by the molecule(s) exhibiting activity. The reaction solution was made by mixing $20 \mu \mathrm{l}$ of the extraction solution with $0.5 \mathrm{mM} 4 \mathrm{MUF}$ $\alpha$-D-glucopyranoside(4MUF-G) (50 mM Tris- $\mathrm{HCl}$ buffer, $\mathrm{pH}$ 7.6) and incubated in the dark at $25^{\circ} \mathrm{C}$ for a maximum of $26 \mathrm{hrs}$. A fluorescence intensity of $440 \mathrm{~nm}$ obtained at an excitation wavelength of $360 \mathrm{~nm}$ was measured in the reaction solution using a fluorophotometer along a time course. A standard curve was made from the 4MUF solution in which the concentration was gradually changed, and the $\alpha$-glucosidase-like activity was calculated from the curve.

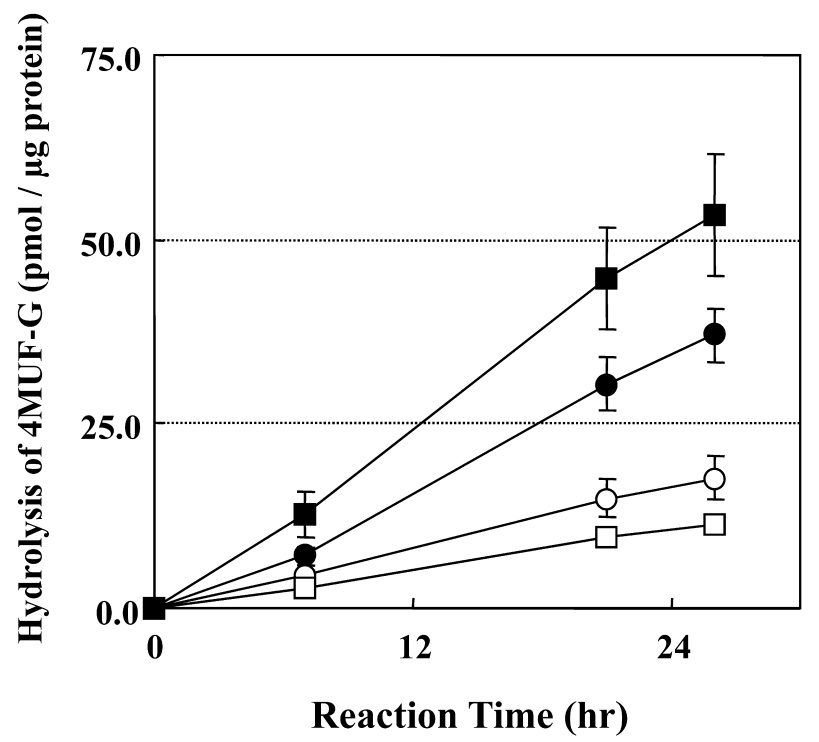

Fig. 1. Changes in $\alpha$-glucosidase-like activity in the beard worm, $O$. mashikoi, over time. $\bigcirc$, anterior section CPF; $\bigcirc$, anterior section MOPF; $\square$, posterior section CPF; $\mathbf{\square}$, posterior section MOPF. Each value is the mean \pm SEM $(\mathrm{N}=5)$.

Table 2. $\alpha$-glucosidase-like activity of the CPF and MOPF from anterior and posterior section.

\begin{tabular}{llc}
\hline & & $\begin{array}{c}\text { 4MUF-G hydrolysis activity } \\
(\mathrm{pmol} / \mu \mathrm{g} \text { total protein } / \mathrm{hr})\end{array}$ \\
\hline Posterior section & CPF & $0.440 \pm 0.040$ \\
& MOPF & $2.046 \pm 0.316$ \\
Anterior section & CPF & $0.681 \pm 0.110$ \\
& MOPF & $1.423 \pm 0.144$ \\
\hline
\end{tabular}

Each value is the mean \pm SEM $(\mathrm{N}=5)$. 


\section{Optimum pH of molecule(s) exhibiting activity}

The optimum $\mathrm{pH}$ was examined by using $50-\mathrm{mM}$ Britton Robinson buffer ( $\mathrm{pH} 4-9.5)$ (50 mM acetic acid, $50 \mathrm{mM}$ boric acid, and $50 \mathrm{mM}$ phosphoric acid) and $50 \mathrm{mM}$ Tris-HCl buffer ( $\mathrm{pH} 7-9)$. That is, 4MUF-G was dissolved in 50-mM Britton Robinson buffer in which the $\mathrm{pH}$ had been adjusted to $\mathrm{pH} 4-9.5$ or in $50 \mathrm{mM}$ Tris- $\mathrm{HCl}$ buffer in which the $\mathrm{pH}$ had been similarly adjusted. We determined which $\mathrm{pH}$ level produced the highest activity when 4MUF-G was decomposed.

\section{Inhibitors of the $\alpha$-glucosidase-like activity}

We examined whether the $\alpha$-glucosidase-like activity was inhibited by known inhibitors of $\alpha$-glucosidase, including acarbose, voglibose, and miglitol. Ten microliters of CPF or MOPF, $180 \mu \mathrm{l}$ of 0.5

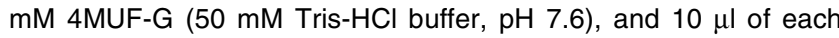
inhibitor, the concentration of which was changed gradually, were mixed and incubated at $25^{\circ} \mathrm{C}$. Hydrolysis to 4 MUF-G when inhib- itors were not added was assumed to be $100 \%$ activity, and the relative activity was calculated for each inhibitor solution. GraphPad Prism 3.03 simulation software (GraphPad Software, San Diego, CA, USA) was used to calculate the $50 \%$ inhibitory concentration.

\section{Substrate Specificity}

We examined whether sucrose, lactose, maltose, maltotriose, or soluble starch is a suitable substrate for the molecule(s) exhibiting activity. Substrate specificity was determined by the production rate of glucose from these substrates. For the measurement of glucose, the Wako Glucose CII test kit (Wako Pure Chemical Company, Osaka) was used.

\section{Zymography}

The two sections, which had been kept in a freezer, were put on a $10 \%$ polyacrylamide gel plate dipped in $2 \mathrm{mM} \mathrm{4MUF-G} \mathrm{and}$ incubated at $25^{\circ} \mathrm{C}$. Every $5 \mathrm{hrs}$, the fluorescence of $4 \mathrm{MUF}$ was

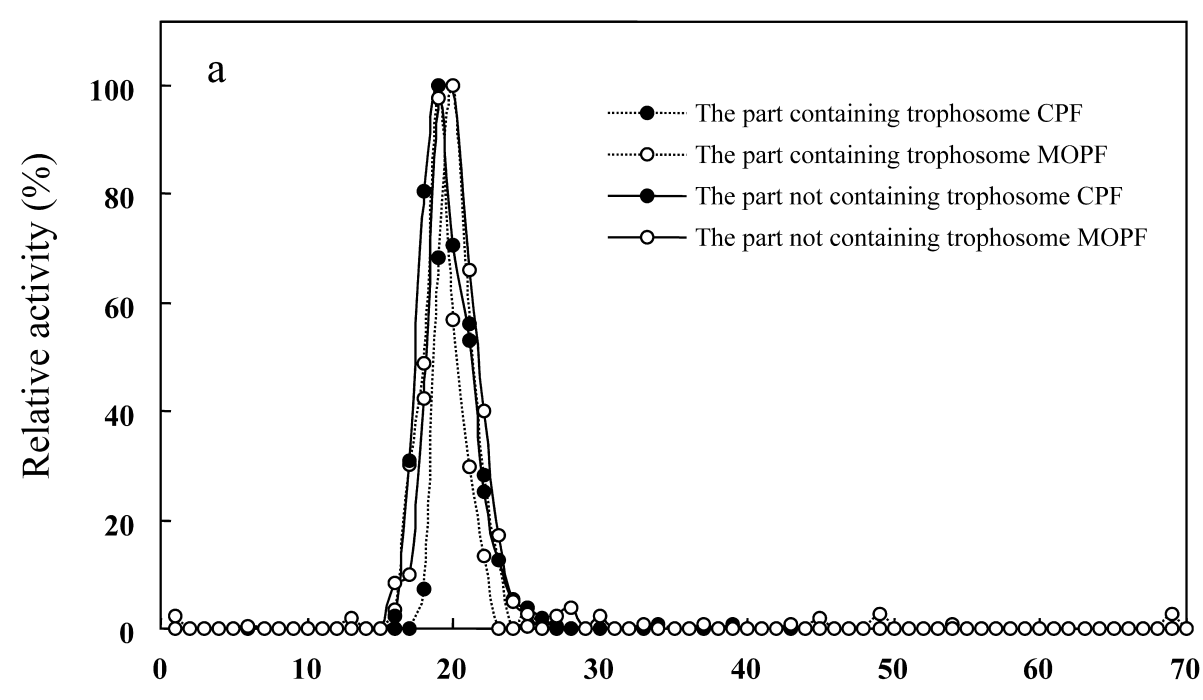

Fraction No.

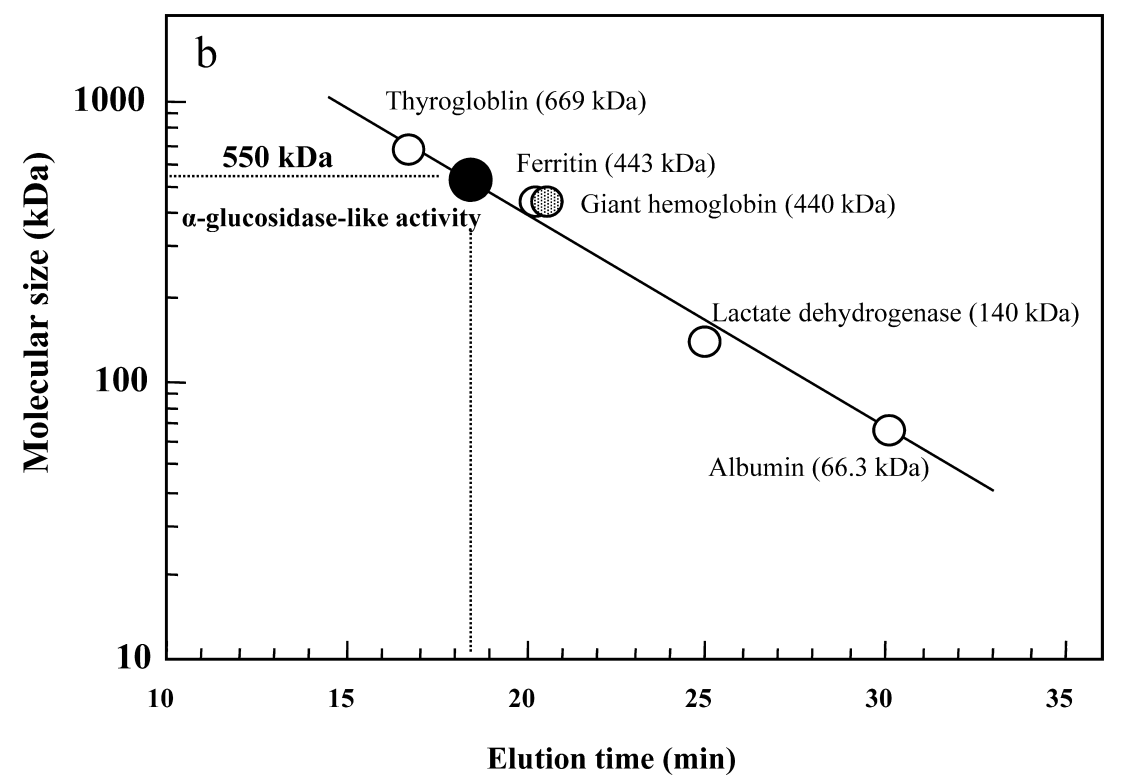

Fig. 2. Gel filtration of $\alpha$-glucosidase-like activity on superdex $200 \mathrm{HR} 10 / 30$. (a) Relative activity of fractions. (b) Molecular weight of the molecule(s) exhibiting a-glucosidase-like activity. 
detected by an image analyzer (Fluo-STM Multilmager, Biorad, Tokyo).

\section{API ZYM assay}

According to the method of Costa and Cruz-Landim (2005), various enzyme activities were examined separately in tissue homogenates of the CPF and MOPF by using an API ZYM system kit (Biomeriux, Tokyo). The homogenate was made of $10 \mathrm{mg}$ wetweight tissue with $1 \mathrm{ml}$ deionized water. The CPF and MOPF were adjusted to contain $500 \mu \mathrm{gl} / \mathrm{ml}$ protein. From these preparations, each $65-\mu \mathrm{l}$ sample was put on a plate and incubated at $37^{\circ} \mathrm{C}$ for 24 hrs. The reaction was then stopped with a ZYM A regent and colorized with $Z Y M B$ regent. The reactions were ranked on a scale of $0-5$, with 0 being no color and 5 being the strongest color.

\section{Immunohistochemical detection of GLUT2}

Tissues were fixed with $4 \%$ paraformaldehyde (PFA) for $24 \mathrm{hrs}$ at $4^{\circ} \mathrm{C}$. They were dehydrated through a sucrose gradient series $(10,20$, and $30 \%$ in PBS) and embedded in an OCT compound (Sakura Finetechnical, Tokyo). The frozen sections, each $8 \mu \mathrm{m}$ in thickness, were washed three times with Tris-buffered saline with Tween 20 (TBST) (pH 8.0) and were incubated for $30 \mathrm{~min}$ at room temperature with a blocking reagent (Roche Diagnostics, Tokyo). The sections were then incubated for $5 \mathrm{hr}$ at room temperature with anti-rat GLUT2 polyclonal antibody (dilution rate 1:2500) (Chemicon International, CA, USA). The sections were washed three times with TBST and then incubated with goat anti-rabbit IgG Cy3 conjugated antibody (diluted 1:1000) (Zymed Laboratories, Basel, Switzerland). Nuclei were stained with DAPI (4',6-diamino-2-phenylindole) $(0.2$ $\mu \mathrm{g} / \mathrm{ml}$ in TBST). After sections were mounted with VECTASHIELD (Vector Laboratories, CA, USA), fluorescence was observed with a BX51-FL microscope system (Olympus, Tokyo).

\section{Western blotting}

Extraction from the two sections was conducted using RIPA lysis buffer (Santa Cruz Biotechnology, CA, USA). The sections were subjected to SDS-PAGE (Laemmli, 1970) on 10\% polyacrylamide gels. Separated proteins were transferred to polyvinylidine difluoride membranes (100V for $1 \mathrm{hr}$ ) and were kept for $1 \mathrm{hr}$ in $5 \%$ $\mathrm{w} / \mathrm{v}$ non-fat dry milk in TBST. Subsequently, they were washed three times, 5 min each time, with $0.5 \%$ non-fat dry milk in TBST. Incubation with the anti-GLUT2 antibody (diluted 1:2500 using $0.5 \%$ non-fat dry milk in TBST) was conducted for $1 \mathrm{hr}$ at room temperature. The membranes were then washed three times, 5 min each time, and incubated for $1 \mathrm{hr}$ in a buffer containing the secondary antibody conjugated with horseradish peroxidase (dilutied 1:10,000) (Santa Cruz Biotechnology, CA, USA). After three washings of 5 min each, the membrane was treated with the $\mathrm{ECL}^{\mathrm{TM}}$ Western Blotting Analysis System (GE Healthcare, UK). The relative abundance of proteins was assayed by densitometry using an image analyzer (Fluo-STM Multilmager, Biorad, Tokyo).

\section{RESULTS}

\section{Environmental factors}

The data obtained in this study, along with those of Sasayama et al. (2007), are shown in Table 1. The water content of the mud inhabited by $O$. mashikoi was about $60 \%$. The seawater of the mud contained $416.0 \pm 39.6 \mu \mathrm{M}$ (glucose equivalents) of carbohydrates and $99.1 \pm 23.7 \mu \mathrm{M}$ of maltoses. Glucose itself was not detected.

\section{$\alpha$-glucosidase-like activity of the crude extraction}

Activity of the CPF and MOPF from the two sections is shown in Fig. 1. Activity was detected in both fractions and did not decline for 26 hrs. Hydrolytic activity to 4MUF-G per total protein was high in the MOPF of both sections but was more conspicuous in the posterior section, which contained the trophosome (Table 2). In the heat-treated extraction $\left(70^{\circ} \mathrm{C}, 10 \mathrm{~min}\right)$, no $\alpha$-glucosidase-like activity was detected in any of the fractions.

\section{Properties of the $\alpha$-glucosidase-like activity}

The activity in the CPF and MOPF was examined using the Con A non-binding fractions with sepharose chromatography (data not shown). In the subsequent separation using a 200 HR 10/30 superdex gel filtration column, activity was detected in fraction 19 in both the CPF and MOPF (Fig. 2a). In addition, in the CPF and MOPF extracted from the whole body of $O$. mashikoi, activity was detected only in fraction

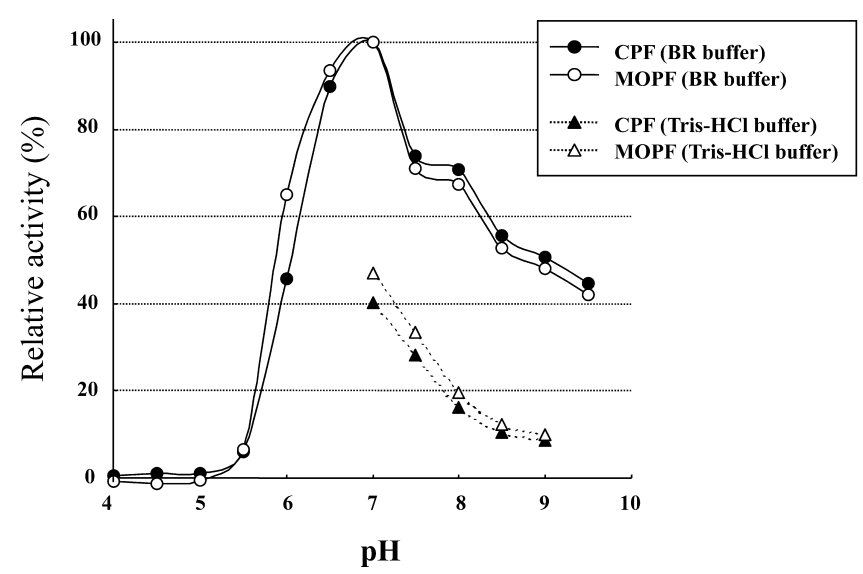

Fig. 3. Effect of $\mathrm{pH}$ on $\alpha$-glucosidase-like activity.

Table 3. Substrate specificity of O.mashikoi $\alpha$-glucosidase-like activity

\begin{tabular}{lcc}
\hline Substrate & & Relative activity (\%) \\
\hline Maltose & Glc- $\alpha-1,4-G l c$ & $100.00 \pm 1.099$ \\
Maltotriose & Glc- $\alpha-1,4-G \mid c-\alpha-1,4-G l c$ & $2.930 \pm 0.366$ \\
Sucrose & Glc- $\alpha-1,2-\beta-$ Fru & Not detected \\
Lactose & Gal- $\beta-1,4-\beta-G l c$ & Not detected \\
Soluble starch & & $1.465 \pm 0.366$ \\
\hline
\end{tabular}

Each value is the mean \pm SEM $(\mathrm{N}=3)$.

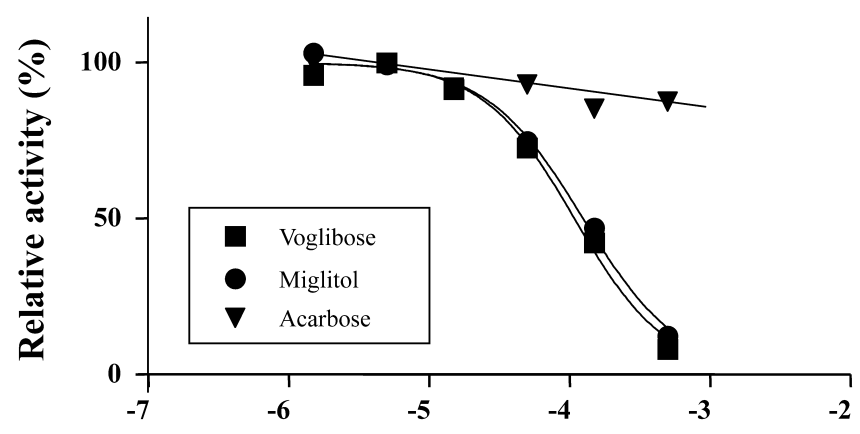

Inhibitor concentration $-\log (\mathrm{M})$

Fig. 4. Effects of three kinds of $\alpha$-glucosidase inhibitors on $\alpha$ glucosidase-like activity. 
19. The molecular weight of the substance(s) exhibiting the activity was estimated to be $550 \mathrm{kD}$ by comparison with the elution times of the marker proteins (Fig. 2b). The activity was high in the range of $\mathrm{pH} 6.0-8.0$ but was not detected in the acidic range lower than $\mathrm{pH} 5.5$ (Fig. 3).

When the active fraction was tested for substrate specificity against polysaccharides including maltose, maltotriose, and soluble starch, it exhibited high specificity only for maltose (Table 3). Furthermore, when acarbose, voglibose, and miglitol were included as $\alpha$-glucosidase inhibitors, voglibose and miglitol dose-dependently decreased the activity of hydrolysis of $4 \mathrm{MUF}-\mathrm{G}$. The $\mathrm{IC}_{50}$ values of voglibose and miglitol were 108 and $125 \mu \mathrm{M}$, respectively. These inhibitors exhibited approximately equal inhibitory effects in all concentration ranges. Acarbose did not show any inhibitory effect, at least at the concentration used (Fig. 4).

\section{Zymography}

The two sections were put on a gel plate including $4 \mathrm{MUF}-\mathrm{G}$ so that $4 \mathrm{MUF}$ would radiate fluorescence as a result of hydrolysis when $\alpha$-glucosidase-like activity was expressed. From the anterior section, fluorescence was observed (Fig. 5D); however, from the posterior section, fluorescence was hardly observed (Fig. 5B).

\section{API ZYM screening}

With the use of the API ZYM system, eight kinds of enzyme activity were found in both sections (Table 4). These activities were higher in the anterior section than in the posterior section.

\section{Immunodetection of GLUT2-like protein}

We observed immunofluorescence in the body surface

\section{The part containing the trophosome}
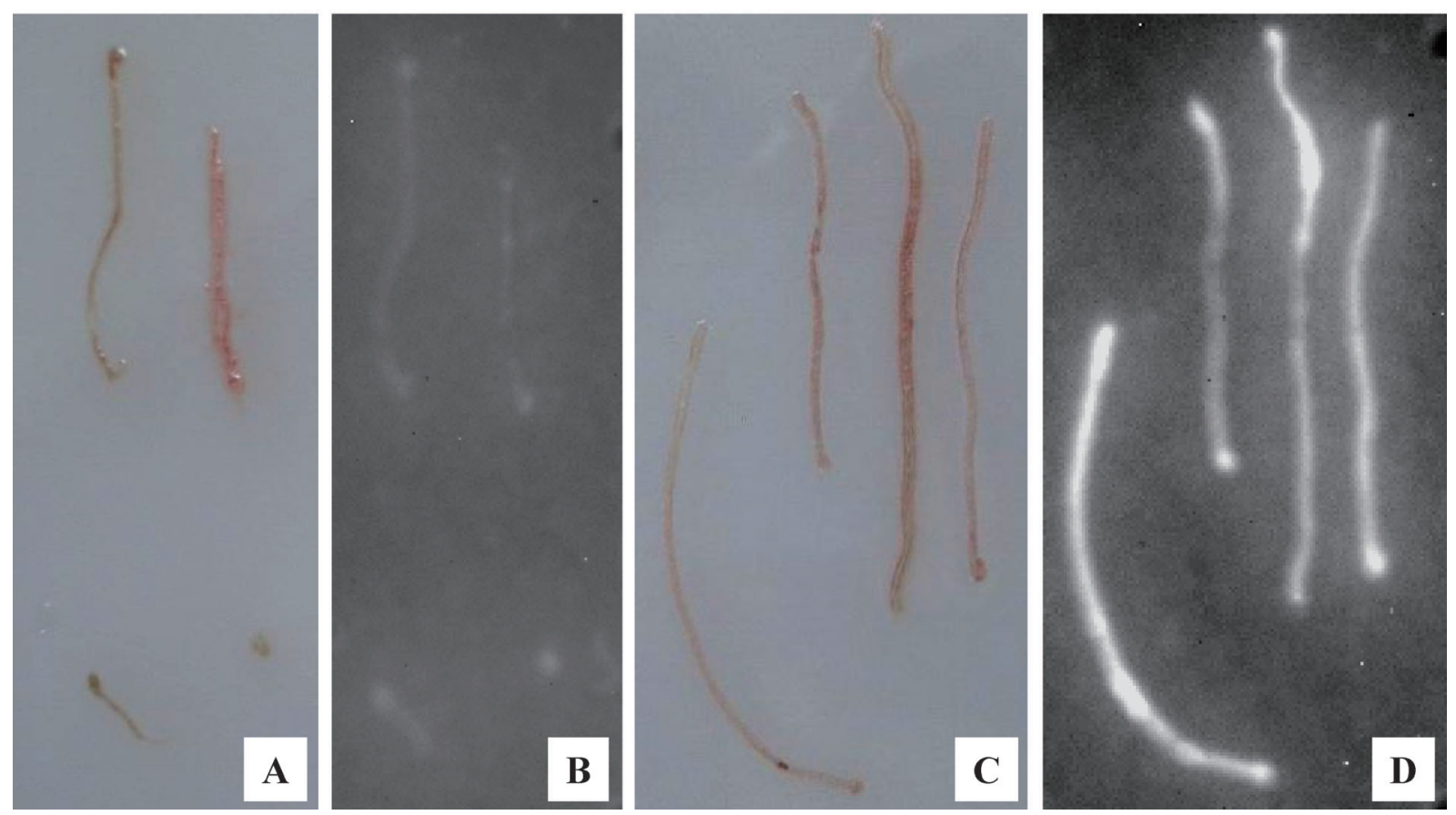

Fig. 5. Photographs showing $\alpha$-glucosidase-like activity detected by gel zymography using 4MUF-G. (A, C) Normal images. (B, D) Fluorescence images.

Table 4. Enzymatic activities of extracts from O. mashikoi

\begin{tabular}{|c|c|c|c|c|c|}
\hline \multirow{2}{*}{ Enzymes } & \multirow{2}{*}{ Whole body } & \multicolumn{2}{|c|}{ Posterior section } & \multicolumn{2}{|c|}{ Anterior section } \\
\hline & & CPF & MOPF & CPF & MOPF \\
\hline$\alpha$-glucosidase & 2 & 1 & 1 & 2 & 2 \\
\hline$\beta$-glucosidase & 3 & 2 & 2 & 3 & 3 \\
\hline$\alpha$-galactosidase & 1 & 3 & 1 & 3 & 3 \\
\hline$\beta$-galactosidase & 3 & 2 & 1 & 3 & 1 \\
\hline$\beta$-glucuronidase & 5 & 3 & 1 & 5 & 3 \\
\hline $\mathrm{N}$-acethyl- $\beta$-glucosaminidase & 5 & 1 & 2 & 4 & 4 \\
\hline$\alpha$-mannosidase & 3 & 1 & 0 & 2 & 2 \\
\hline$\alpha$-fucosidase & 3 & 1 & 1 & 2 & 2 \\
\hline
\end{tabular}

$0=$ no activity; $5=$ highest activity. 

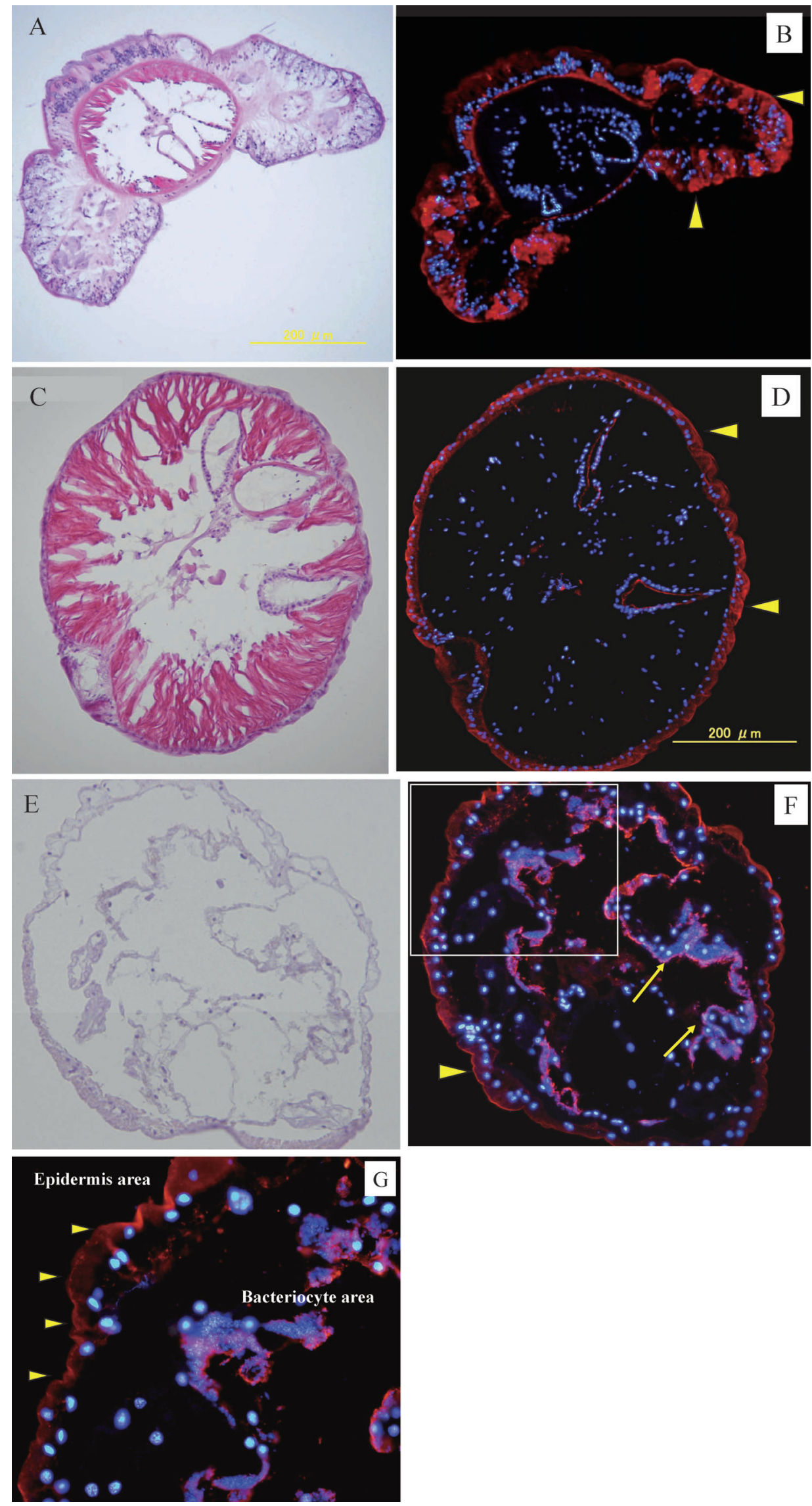

Fig. 6. Immunolocalization of the GLUT2-like protein in $O$. mashikoi. Photographs of HE stain (A, C, E) and of the immunofluorescence reaction (B, D, F). The adhesive ventral papillae region (A, B) and the pre-annular trunk region $(\mathbf{C}, \mathbf{D})$ do not contain the trophosome. The section shown in (E) and $(\mathbf{F})$ contains the trophosome. (G) Enlargement of the square in $F$. 
of the anterior section, indicating the presence of GLUT2like protein (Fig. 6B, D). The fluorescence was especially conspicuous in the apical portion of the epidermis. In the epidermis of the posterior section, similar but weaker immunofluorescence was observed (Fig. 6F, G). In the trophosome, however, an intense immunoreaction was obtained in the bacteriocyte area (Fig. 6F, G). Western-blot analysis revealed that a band of about $60 \mathrm{kDa}$ was present in the homogenates from the two parts. The size of this band was consistent with the molecular size of GLUT2 extracted from rat duodenum villus (Fig. 7).

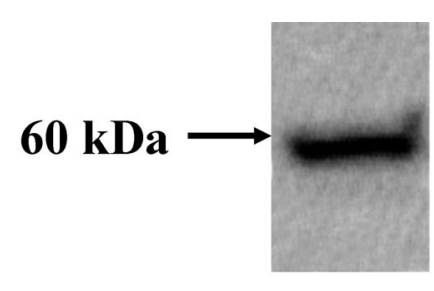

A

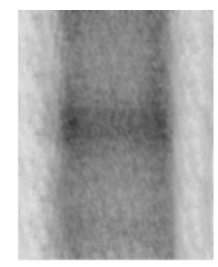

B

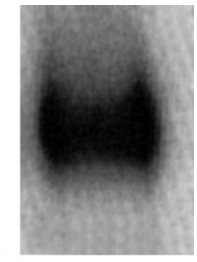

C
Fig. 7. Western-blot analysis with anti-rat GLUT2 antibody of homogenates of $(\mathbf{A})$ rat duodenum villus and $(B)$ the posterior section and (C) anterior section of O. mashikoi. Arrow shows the position of migration of a $60-\mathrm{kDa}$ protein (from standard).

\section{DISCUSSION}

Although glucose was not detected among the organic substances in the environment inhabited by O. mashikoi, several tens to hundreds micromolar concentrations of maltoses and carbohydrates were found. These molecules may be hydrolyzed under natural conditions by polysaccharide hydrolytic enzymes such as $\alpha$-glucosidase or $\alpha$-amylase, increasing to double or more the original number of glucose molecules. Therefore, the quantity of these carbohydrates seems sufficient to be an environmental source of glucose.

Southward et al. (1981) reported that in their experiment, beard worms inhabiting the deep sea may have the ability to take in through the skin glucose from the environment. If their interpretation of the results is correct, the body surface of beard worms must have a mechanism allowing them to take in monosaccharides. We observed $\alpha$ glucosidase-like activity in the MOPF and CPF of both sections, regardless of the presence of the trophosome, suggesting that this activity is localized in the cellular membrane and organelles. The activity in the two sections may originate in the same molecule(s) since the activity in the MOPF and CPF of both sections had a single peak in Con$A$ affinity chromatography and superdex gel filtration with the same retention time. Therefore, the molecule(s) exhibiting the $\alpha$-glucosidase-like activity seemed to be substance(s) produced by $O$. mashikoi itself, not by symbiotic bacteria harbored in the trophosome.

The size of the molecule(s) was estimated to be 550 $\mathrm{kDa}$, whereas the largest known molecular size of $\alpha$ glucosidase is $150 \mathrm{kDa}$ (Krasikov et al., 2001). In the digestive tract of mammals, there are digestive enzyme complexes such as the sucrase-isomaltase complex. Consequently, a giant type of $\alpha$-glucosidase combined with other molecules may be possible, as seen in the giant hemoglobin of this species (Nakagawa et al., 2005).

When substrate specificity was examined, the highest activity of the molecule(s) was obtained with maltose. Furthermore, since the activity was inhibited by voglibose and miglitol, which are known inhibitors of $\alpha$-glucosidase, it may be reasonable to assume that the molecule(s) has properties very similar to those of $\alpha$-glucosidase. It is known that acarbose hardly acts on $\alpha$-glucosidase in rat small intestine, although it is an inhibitor in other animals (Kuboyama et al., 2006). On the other hand, acarbose displays strong inhibitory activity for $\alpha$-amylase (Scott and Spencer, 2000). In our study, the activity of the molecule(s) was not inhibited by acarbose. In addition, the molecule(s) exhibited no amylase activity. These results indicate that the main action of the molecule(s) may be in the digestion of maltose.

The anterior and posterior sections were incubated on a gel plate containing 4MUF-G. This plate generated fluorescence when 4 MUF-G was hydrolyzed by an $\alpha$-glucosidaselike molecule(s). However, the results were remarkably different for the two sections in that fluorescence by 4MUF was observed only on the surface of the anterior section.

Immunofluorescence exhibiting the presence of GLUT2 was detected in the epidermis of the body surface and was especially clear in the anterior section of the body. The size of this protein was almost the same as that of rat GLUT2. Caccia et al (2005) detected facilitative GLUT2-like transporters in midgut epithelial cells of Aphidius ervi lavae by using the same antibody as that used in this study. Our results may support the past discussion by Southward et al. (1981). On the other hand, a GLUT2-like transporter was also detected in the bacteriocyte area of the trophosome, where the symbiotic bacteria are thought to produce carbohydrates. Therefore, this GLUT2-like molecule(s) may be involved in the transport of monosaccharides.

Oligobrachia mashikoi lives perpendicular to the sea bottom, its tube projecting $5 \mathrm{~mm}$ from the sea bottom and its tentacles protruding slightly from the tube. Hydrogensulfide levels in the portion of the sea bottom where this species lives are high at the floor surface but decrease sharply in deeper mud. Total nitrogen levels show a similar pattern (Sasayama et al., 2007). In other words, organic substances are present only in the mud surrounding the anterior section of the body. When the result of zymography is considered, this fact is especially interesting. Furthermore, the optimum $\mathrm{pH}$ for the molecule(s) exhibiting $\alpha$-glucosidase-like activity is in the vicinity of $\mathrm{pH} 6-8$, which seems reasonable considering the $\mathrm{pH}$ of the environmental seawater. In the posterior section, which is in deeper mud, the molecule(s) may participate in the metabolism of carbohydrates stocked in the nutrient-deposit cells of the trophosome.

In conclusion, we detected $\alpha$-glucosidase-like activity and a GLUT2-like protein in the surface of the anterior body and in the trophosome of $O$. mashikoi. The results raise the questions whether these molecules function to take in monosaccharides from the environment, or to transfer monosaccharides to other cells and the bloodstream. To clarify this problem, further biochemical studies are necessary. 


\section{ACKNOWLEDGMENTS}

We thank Mr. Masahiro Matada, a member of the technical staff of Noto Marine Laboratory, for his help with the sampling of $O$. mashikoi. We also thank Mr. Tetsuya Yamada for his precise technical support in immunostaining.

\section{REFERENCES}

Bright M, Sorgo A (2003) Ultrastructural reinvestigation of the trophosome in adult of Riftia pachyptila (Annelida, Siboglinidae). Invertebr Biol 122: 345-366

Caccia S, Leonardi MG, Casartelli M, Grimaldi A, de Eguileor M, Pennacchio F, Giordana B (2005) Nutrient absorption by Aphidius ervi larvae. J Insect Physiol 51: 1183-1192

Costa RA, da Cruz-Landim C (2005) Hydrolases in the hypopharyngeal glands of workers of Scaptotrigona postica and Apis mellifera (Hymenoptera, Apinae). Genet Mol Res 4: 616-623

Deguchi $M$, Kubota $N$, Matsuno A, Kanemori M, Fukumori $\mathrm{Y}$, Sasayama Y (2007) Actual distribution of bacteriocytes in the trophosome of a beard worm (Oligobrachia mashikoi, Siboglinidae, Annelida): clarification using whole-mount in situ hybridization. Acta Zool 88: 129-135

Kellet GL (2001) The facilitated component of intestinal glucose absorption. J Physiol 531: 585-595

Krasikov VV, Karelov DV, Firsov LM (2001) $\alpha$-Glucosidases. Biochemistry (Moscow) 66: 267-281

Kuboyama N, Hayashi I, Yamaguchi T (2006) Pharmacokinetic, pharmacological, and clinical profile of miglitol (SEIBULE ${ }^{\circledR}$ ), a novel alpha-glucosidase inhibitor. Folia Pharmacol Jpn 127: 223-232 (Japanese)

Mita M, Deguchi M, Sasayama Y (2006) Lipid composition of the trophosome in the beard worm, Oligobrachia mashikoi (Pogonophora). J Mar Biol Assoc UK 86: 283-286
Nakagawa T, Onoda S, Kanemori M, Sasayama Y, Fukumori Y (2005) Purification, characterization and sequence analyses of the extracellular giant hemoglobin from Oligobrachia mashikoi. Zool Sci 22: 283-291

Roach PJ (2002) Glycogen and its metabolism. Curr Mol Med 2: $101-120$

Sasayama Y, Matada M, Fukumori Y, Umebayashi M, Matsuno A, Nakagawa T, Imajima M (2003) External morphology of posterior end, the "opisthosoma", of the beard worm Oligobrachia mashikoi (pogonophora). Zool Sci 20: 1411-1416

Sasayama Y, Higashide Y, Sakai M, Matada M, Fukumori Y (2007) Relationship between the lifestyle of a siboglinidae polychaete, Oligobrachia mashikoi (also known as Pogonophora), and the total sulfide/nitrogen levels in its habitat. Zool Sci 24: 131-136

Scott LJ, Spencer CM (2000) Miglitol: a review of its therapeutic potential in type 2 diabetes mellitus. Drugs 59: 521-549

Shulze A, Halanych KM (2003) Siboglinid evolution shaped by habitat preference and sulfide tolerance. Hydrobiologia 496: 199205

Southward AJ, Southward EC (1972) Observation on the role of dissolved organic compounds in the nutrition of benthic invertebrates. III. Uptake in relation to organic content of the habitat. Sarsia 50: 29-46

Southward AJ, Southward EC (1981) Dissolved organic matter and the nutrition of the pogonophora: a reassessment based on recent studies of their morphology and biology. Kieler Meeresforsch Sonderh 5: 445-453

Southward EC (1982) Bacterial symbionts in Pogonophora. J Mar Biol Assoc UK: 889-906

(Received December 3, 2007 / Accepted January 30, 2008) 